\title{
A plea for varieties of entrepreneurship
}

\author{
Andrea M. Herrmann
}

Accepted: 16 August 2018 /Published online: 18 September 2018

(C) The Author(s) 2018
Keywords Entrepreneurship - Varieties of capitalism . National institutions $\cdot$ Institutional complementarities

JEL classifications $\mathrm{L} 26 \cdot \mathrm{M} 13 \cdot \mathrm{D} 02 \cdot \mathrm{O} 31 \cdot \mathrm{L} 5$

\section{Introduction}

Over the past two decades, the Varieties-ofCapitalism (VoC) literature-going back to the work of Hall and Soskice (Hall and Soskice 2001a) - have become a widely applied framework in the political sciences, in political economy and economic sociology alike. In a nutshell, the $\mathrm{VoC}$ literature illustrates that different national institutions governing labour and financial markets as well as inter-organisational collaborations facilitate different types of corporate innovation. While the VoC framework has been developed mostly through studies of incumbent firms, its reasoning is equally applicable to new ventures: national institutions are likely to lead also new ventures to develop business ideas of different innovations. To put it differently, given that incumbent firms were found to compete on different types of innovations and, thus, in different market segments between countries, it is reasonable to expect that many firms have chosen these competitive strategies from their inception as new ventures.

However, to date, the VoC framework has hardly been applied in entrepreneurship research (for exceptions, see Dilli et al. 2018; Held et al. 2018;
Innovation Studies Group, Copernicus Institute of Sustainable Development, Utrecht University, Utrecht, The Netherlands e-mail: A.M.Herrmann@uu.nl 
see also Ebner 2010; van der Walt 2010). ${ }^{1}$ To be clear, the entrepreneurship literature illustrates that entrepreneurs are driven by different motives and engage in entrepreneurship for different reasons and that entrepreneurs have diverse aspirations and different growth ambitions (for example Cooper and Artz 1995; Wiklund et al. 2003). The literature acknowledges that different forms of entrepreneurship exist, ranging from solo selfemployment over small family businesses to highgrowth gazelle ventures (see also Delmar et al. 2003; Henrekson and Stenkula 2016; Vivarelli 2013). The Global Entrepreneurship Monitor-by far the most comprehensive dataset on entrepreneurship forms across the world-also illustrates that entrepreneurship takes numerous different forms between countries. However, systematic research into how and why entrepreneurship between countries may differ in their innovation focus remains underdeveloped.

This research gap has been supported by a strong focus on radically innovative - that is "technologyintensive" (OECD 1998), "R\&D intensive" (Schreyer 2000) or "knowledge intensive" (Delmar et al. 2003) _ ventures, which have been theoretically motivated by their high growth potential, because these ventures have been shown to generate a disproportionately high amount of employment (see also Amat and Perramon 2010; Davidson and Segerstrom 1998; Hölzl 2009; OECD 2002; Shane 2009). Radically, innovative ventures typically develop goods based on new technologies, leading to strong corporate growth on the one hand and a superior risk of failure on the other. Examples of such radically innovative ventures have emerged particularly frequently in Silicon Valley which, in turn, has led to an idolisation of this radically innovative, "Silicon Valley" entrepreneurship: Newspapers report with particular frequency about the heroic efforts and outstanding success of Silicon Valley entrepreneurs, and mainstream movies have been made about the start-up stories of Apple and Facebook. Because attention and impact have accrued to studies of extraordinary rather than every-day phenomena, scientific research has paid

\footnotetext{
${ }^{1}$ The reason why the VoC framework has hardly been applied in business and management research today seems straight-forward: The core proponents of the VoC arguments, as well as their followers, are political scientists (Peter Hall, Kathleen Thelen), political economists (David Soskice) and sociologists (Wolfgang Streeck) rather than business and management scholars.
}

inordinate attention to the (funding and other) needs along with the impact of radically innovative ventures (see, for example, Henrekson and Johansson 2010; Shane 2009). And as a consequence, policymakers across Europe explicitly or implicitly aim to facilitate high-growth (Silicon Valley) entrepreneurship back home (Commission 2010; OECD 2002; see also Hölzl 2009; Mason and Brown 2013: 214).

Importantly, though, this focus on radically innovative entrepreneurship is problematic for various reasons: First, it conveys the impression that less innovative types of entrepreneurship are second best as they grow less rapidly (see, for example, Amat and Perramon 2010; Davidson and Segerstrom 1998; Hölzl 2009; OECD 1998; OECD 2002; Schreyer 2000). This reasoning seems however flawed as recent studies show that high employment growth is generated not only by highly innovative start-ups but also by more established firms of at least 5 years (Anyadike-Danes et al. 2009) and with an average age of 25 years (Acs et al. 2008a). Furthermore, a recent study of the German ministry of economic affairs finds that "high growth ventures can as well shrink again. A high growth venture (...) is thus no guarantee for sustained employment growth but constitutes a temporary phenomenon" (BMWi 2012: 42). Second, the focus on radically innovative entrepreneurship is also problematic because it neglects the comparative institutional advantage that continental European economies offer to incrementally innovative start-up firms. This neglect is particularly problematic because - even in the USA - radically innovative ventures occur much less frequently than their incrementally innovative counterparts. While across economies most new ventures are not innovative, amongst those that are, incremental innovation is the rule, and radical innovation is the exception (see Baumol 2002; Baumol 2004; Henrekson and Sanadaji 2014: 1760; Nightingale and Coad 2014).

Addressing these problems, I here argue that entrepreneurship studies would benefit from a Varieties-ofCapitalism approach as this illustrates the extent to which different types of innovation exist amongst new ventures. Insights into how national institutions stimulate such varieties of entrepreneurship would allow today's entrepreneurship research to move away from its focus on radically innovative entrepreneurship as the most desirable entrepreneurship type. As a consequence, policymakers might become less focused on fostering Silicon Valley entrepreneurship in Continental 
Europe which, according to the $\mathrm{VoC}$ reasoning, is a rather fruitless endeavor anyway because national institutions facilitate the development of incrementally innovative entrepreneurship and provide less support for radical innovation (see also Ebner 2010). In sum, a better understanding of the varieties of entrepreneurial innovativeness would lead to a more balanced understanding of the possibilities and need - or rather the difficulties and needless efforts - to foster radically innovative entrepreneurship in different institutional environments.

To illustrate how the $\mathrm{VoC}$ reasoning offers a more balanced understanding of the link between national institutions and different types of entrepreneurial innovativeness, I first review the core arguments of the $\mathrm{VoC}$ literature on a country's institutional foundations in Section 2. In line with these theoretical illustrations, I provide (in Section 3) an overview of the existing empirical evidence on the extent to which new ventures in Germany and the USA differ in their innovativeness. In Section 4, I illustrate the implications that result for research and policymakers from these findings.

\section{Theoretical foundations}

Starting with the work of Stinchcombe (1965), the entrepreneurship literature investigating how institutions influence entrepreneurship gained momentum in the early 1990s. Its contributors arrived at the conclusion that institutions "matter", because they structure economic payoffs which influence entrepreneurial efforts and activities (Calcagno and Sobel 2014; Baumol 1990; Murphy et al. 1990; Sobel 2008). While the literature agrees that both formal and informal institutions incentivize individual behaviour (North 1990), thereby influencing the extent and character of an economy's entrepreneurial activity (Acs et al. 2008b; Stenholm et al. 2013; Urbano and Alvarez 2014), it also _often implicitly - focuses on the institutional drivers of radically innovative entrepreneurship: Formal institutions that were found to be beneficial for "productive", "high growth" entrepreneurship include law and order, contract enforcement, competition policy, trade policies, tax codes, social insurance systems, employment protection legislation, capital market regulation as well as the protection of private property (Bjørnskov and Foss 2013; Hall and Jones 1999; Henrekson and Johansson 2009). Informal institutions supporting growth-oriented entrepreneurship encompass individualism, social capital, trust and power distance (Hechavarria and Reynolds 2009; Taylor and Wilson 2012). In short, the current literature suggests that differences in entrepreneurship between countries or regions can, inter alia, be explained by a broad diversity of institutions (Case and Harris 2012; Stam 2014; World Economic Forum 2013).

Relatedly, the literature on institutions and entrepreneurship suffers from three problems: First, a clear-cut concept of institutions is missing. Second, a parsimonious understanding of whether and how a few core institutions facilitate different types of entrepreneurship is not provided. Third, the literature focuses on explaining how different types of institutions foster high growth or "high impact" entrepreneurship (Davidsson and Henrekson 2002; Henrekson 2005; Henrekson and Johansson 2009). While this leads the literature to focus on technology-intensive (OECD 1998), R\&D intensive (Schreyer 2000) or knowledge intensive (Delmar et al. 2003) ventures, incrementally, innovative ventures, their needs and institutional drivers tend to be overlooked.

The VoC literature makes it possible to address these three problems. First, the VoC literature clearly defines institutions as "formalized rules that may be enforced by calling upon a third party" (Streeck and Thelen 2005: 10). Institutions thus are the written or verbally agreed rules of the game which lead to a systematic behaviour of actors (individuals and organisations), i.e. of entrepreneurs and their ventures.

Second, the VoC literature offers a parsimonious theoretical framework to identify a core of institutions which influence any business activity (Hall and Soskice 2001b). To this end, the VoC literature draws on the insights of economic theory (Milgrom and Roberts 1992; Teece and Pisano 1998; Williamson 1985) as well as the resource dependence view (Pfeffer and Salancik 1978), which illustrate that three types of resources are essential for any business to operate: labour, finance and know-how. These resources are considered as most important, because firms can only secure them after solving a collective action problem with external economic actors, namely their workforces, financiers and $R \& D$ partners. Institutions channelling the interaction between firms and their workforces, financiers and R\&D partners can therefore offer comparative advantages and are thus considered to be economically most influential. Accordingly, the VoC literature explains how educationrelated together with labour-market institutions, financerelated institutions and institutions governing inter- 
organisational collaborations are shaped differently between countries, thus leading to different institutional environments on the one hand and different types of corporate behaviour on the other.

Third, based on these theoretical considerations, the VoC literature convincingly argues that incrementally innovative firms are institutionally supported by a regulated institutional environment. To illustrate this point, the VoC literature (Hall and Soskice 2001a) compares the institutional environment of liberal market economies (LMEs) to that of coordinated market economies (CMEs). In doing so, the VoC scholars often illustrate their reasoning at the examples of Germany, which they consider the most typical CME, and the USA, which is considered the most typical LME. Later contributors to the VoC literature questioned the dichotomous distinction between CMEs and LMEs as they identified additional institutional constellations of country groups, most notably Mediterranean market economies (MMEs) and Eastern market economies (EMEs) (for example Amable 2003; Hancké et al. 2007; Schneider and Paunescu 2012). While this paper does not question that more varieties of capitalism can be observed than CMEs and LMEs, it is analytically not necessary to develop my argument (that varieties of entrepreneurship exist) for numerous different institutional constellations. To illustrate that radically innovative entrepreneurship is facilitated by a deregulated institutional setting, whereas other institutional constellations facilitate different types of entrepreneurship, the paper also focuses on the original VoC dichotomy, taking the USA and Germany as most typical examples of LMEs and CMEs respectively.

Applying the VoC reasoning to new ventures confirms the arguments of the entrepreneurship literature that the institutional environment of the USA is particularly conducive to high-growth, radically innovative entrepreneurship.

To begin with labour, the VoC literature highlights the free-riding problem related to the training of appropriately skilled workforces (Estevez-Abe et al. 2001; Hall and Soskice 2001b). Given that the US education and training system is not coordinated via a countrywide dialogue between the social partners, sophisticated industry-wide job classifications that could serve as a basis for training workforces do not exist. Workforces therefore acquire a versatile skill set which they can use in different work environments. Upon completion of education trajectories, the flexible labour-market institutions of the USA further strengthen the general skills of US workforces. Short notice periods, dismissal without substantial reasons and weak works councils imply that workforces are faced with hire-and-fire at short notice. Employees therefore acquire general skills that are useful for, and thus adequately rewarded by, all firms needing a certain business function. Importantly, such general skills facilitate radical innovations and new business ideas as employees are particularly imaginative and flexible in adapting to new corporate environments because of their frequent job changes (see also Herrmann and Peine 2011). The flexible education and labour-market institutions of the USA thus facilitate the development of radically innovative ventures as they equip workforces with general skills.

In addition to labour-market institutions, also those institutions ruling the access to venture finance facilitate the development of radically innovative ventures. The VoC literature illustrates that institutions differ in how they address the principal-agent problem related to the provision of shareholder capital (Hall and Soskice 2001b; Kenyon and Vitols 2004; Vitols 2001): To be willing to invest, shareholders need to be assured that their funds are used in the most efficient way by the firm's management. In the USA, supervisory boards overlooking the activities and decisions of the board of directors are unknown. While shareholders directly elect corporate managers, they have no systematic insights into, or control over, their activities via a supervisory board. Consequently, managers have unilateral power to take major strategic and financial decisions, while shareholders can monitor the soundness of managerial decisions only through the development of equity prices at the stock market. This, in turn, drives managers to maximize returns on investment by engaging in highrisk, radical innovation projects. Radically, innovative start-ups are therefore a particularly attractive investment option for venture capitalists. Venture capital investments into start-up firms are furthermore facilitated by the US private pension system, which implies that comparatively high sums destined to build up future pensions are invested inter alia in venture capital firms. Accordingly, the US pension and corporate governance systems also facilitate the development of radically innovative ventures.

The VoC literature furthermore highlights how the US solution to hold-up problems, related to interorganisational development of know-how, facilitates the emergence of radically innovative ventures (Hall and Soskice 2001b; Tate 2001; Teubner 2001). Firms 
often engage in $R \& D$ collaborations with other organisations - such as research labs, universities or suppliers - in order to jointly develop new products or services (Lundvall 1992b; Tate 2001: 444-446). But such joint developments also bear the risk of hold-up. The latter occurs whenever two or more actors try to appropriate the intellectual property (IP) developed by their cooperation partner/s without having equally contributed to this knowledge development (see Klein 1996; Rogerson 1992: 777). Institutions governing inter-firm collaborations influence the ways in which companies can protect themselves against such IP theft, depending on how institutions facilitate the enforcement of R\&D contracts between collaboration partners (Tate 2001; Teubner 2001): In the USA, the case-by-case decisions of lay juries or judges make the outcome of lawsuits unpredictable. Consequently, firms often shy away from approaching courts to have the contractual obligations of their R\&D collaboration partners enforced. This, in turn, does not only discourage largescale cooperation, but it also stimulates fierce competition between potential collaboration partners, which is at the basis of radical innovation.

While the VoC literature makes it possible to explain why radically innovative ventures occur with particular frequency in the Anglo-Saxon LMEs, most notably in the USA, it also points out that the regulated institutional environment of CMEs, in particular of Germany, facilitates the development of incrementally innovative ventures.

With regard to labour skills, the VoC literature highlights how German workforces engaging in secondary education are trained in company specific skills thanks to the "Duales System", a nation-wide vocational training programme (Hall and Soskice 2001b). The dual system, established and constantly developed by the social partners, offers sophisticated training trajectories to future workforces in close collaboration with companies, aiming at hiring their trainees upon completion. Aware that their dual degree programme is likely to translate into permanent employment at the training firm, workforces are willing to acquire companyspecific skills which they can use only within the context of their company. The acquisition of companyspecific skills by Germany's workforces is furthermore strengthened by regulated labour market institutions: German employees cannot be hired and fired at will. Unless they fall under exempt regulations (such as startup companies of up to ten employees), ventures can only dismiss employees for limited reasons, after respecting specific notice periods and involving the venture's works council. Also, temporary forms of employment are strongly protected with the intention to gear them towards permanent employment (Estevez-Abe et al. 2001). Given that these institutions tie employees to the same firm for a long time period, employees in Germany tend to have in-depth corporate knowledge and long-standing relationships with their firm's suppliers. Such firm-specific skills enable Germany's workforces to autonomously propose and develop improvements which translate into incremental innovations and high-quality products (Herrmann and Peine 2011).

Also, the German pension and corporate governance systems, institutionalising the access of ventures to $f i$ nance, facilitate the development of incrementally innovative ventures (Hall and Soskice 2001b; Kenyon and Vitols 2004; Vitols 2001): To begin with, venture capital is comparatively scarce - inter alia because Germany's public pension system is a pay-as-you-go scheme. Accordingly, the pension provisions paid in by the current working population are directly redistributed by the state to Germany's retirees and not invested into profityielding projects, let alone venture capital funds. Once limited liability ventures reach a certain size, a supervisory board needs to be established including employee as well as shareholder representatives. Given that the supervisory board needs to agree to major strategic investment decisions, managers have no unilateral decision-making power. On the one hand, this makes it difficult to rapidly invest into, or divest from, new business units, which are often necessary for radical innovations. On the other hand, shareholders with insights into, and a say about, how their funds are to be used are typically less interested in maximising returns on investment in the short run. This is particularly true as members of supervisory boards often represent major corporate stakeholders, such as the firm's "house banks" or suppliers. The board members therefore tend to have a preference for their firm to engage in incrementally innovative projects, because they typically have more stable and predictable - albeit lower-returns in the long run.

Furthermore, the hold-up problem related to joint know-how development with R\&D partners is overcome by the code-based legal system of CMEs in general and of Germany in particular (Hall and Soskice 2001b; Tate 2001; Teubner 2001). Because of the clearly defined conditions for IP infringements, the outcome of lawsuits 
is better predictable. Contractual obligations of $R \& D$ collaborations can therefore be enforced in a straightforward manner, which limits the risks of uncompensated IP appropriation by a collaboration partner. Additionally supported by the fairly reliable and efficient legal system, firms in Germany have a higher propensity to engage in R\&D collaborations on a large scale. This, in turn, facilitates incremental product improvements rather than radical innovations.

To conclude, the VoC literature highlights how a distinct set of education-related and labour-market institutions, as well as institutions influencing the access to shareholder capital and opportunities for joint R\&D collaborations support different types of entrepreneurship: While the institutional environment of the USA facilitates the development of radically innovative ventures, Germany's institutions lead entrepreneurs to rather set-up incrementally innovative ventures.

\section{Empirical evidence}

If the $\mathrm{VoC}$ reasoning about the impact of institutions on entrepreneurial innovativeness is indeed applicable, we would expect to find an above-average share of radically innovative ventures in the USA and an elevated proportion of incrementally innovative ventures in Germany. Several studies lend preliminary empirical support to this idea, whereby comprehensive data to assess venture innovativeness is, thus far, hardly available.

With regard to a venture's innovativeness, the $\mathrm{VoC}$ as well as the innovation and strategy literatures convincingly argue that ventures can compete through three distinct innovation strategies: radical innovation, incremental innovation and imitation. More specifically, a venture can compete by developing a hitherto unknown good (product or service), which is usually based on a radically new technology, thereby enabling radical innovation (see Casper 2001: 398; Estevez-Abe et al. 2001: 149, 174; Hall and Soskice 2001b: 38-39; Lundvall 1992a: 11-12; Lundvall 1992c: 58-59). Alternatively, ventures can develop products or services that are already known. In this case, the good needs to be either better (i.e. of a superior quality) or cheaper than the ones of competitors. An improved good is often based on an incrementally new technology which the firm achieves by ameliorating an existing technology. This enables firms to compete through incremental innovation (see in particular Streeck 1991; see also Casper
2001: 399-400; Estevez-Abe et al. 2001: 148-149, 174; Hall and Soskice 2001b: 39; Lundvall 1992a: 11-12; Lundvall 1992c: 57-58; Porter 1985: 14). To develop cheaper products or services, ventures do typically not engage in any technological development but reproduce existing goods at the lowest possible costs, thereby competing through imitation (see Casper 2001: 398399; Estevez-Abe et al. 2001: 148, 175; Porter 1985: 12-14).

While the entrepreneurship literature researches into venture differences regarding their innovativeness and technology orientation, also as predictors of their growth potential, entrepreneurship studies tend to make dichotomous distinctions, that is, scholars distinguish between innovative and imitative ventures on the one hand (Davidson and Segerstrom 1998; Minniti and Lévesque 2010; see also Amat and Perramon 2010; Hölzl 2009) and between and high-tech and low hightech ventures on the other (see OECD 2002; Schreyer 2000). Importantly, though, these dichotomous differentiations overlook the possibility of incremental innovativeness: They foreclose a distinction between radical and incremental innovation next to imitation. Similarly, they do not differentiate between high-tech, mediumtech and low-tech ventures.

While the dichotomous orientation of the entrepreneurship literature may well be caused by the inherent difficulty to measure different degrees of innovativeness, the VoC literature proposes overall three different approaches to distinguish between radial and incremental innovation. Based on these indicators, some empirical evidence exists for the idea that the institutional environment of the USA facilitates the development of radically innovative ventures, while Germany's institutions promote incrementally innovative ventures.

Like many VoC studies, Dilli et al. (2018) take the technology intensity of industries as a pars-pro-toto indicator of entrepreneurial innovativeness. Based on the Eurostat classification of "high-tech industry and knowledge-intensive services" (Eurostat 2016: appendix 3 ), the authors find that the share of new ventures that are registered in high-tech industries is significantly higher in LMEs (including the USA) than in Continental, Eastern and Southern European economies. Similarly, the registration and growth of new ventures in lowand-medium-tech sectors are significantly higher in CMEs (including Germany) than in LMEs as well as in Eastern and Southern European economies (Dilli et al. 2018: table 5). 
While these findings are overall in line with the $\mathrm{VoC}$ expectations, the technology intensity of entire industries as an indicator of a venture's innovativeness also bears a major problem: All firms active in the same industry are necessarily found to be equally technology intense or innovative. To give an example, all firms active in the biotechnology industry are classified as high-tech firms and, thus, as radically innovative, whereas firms active in the pharmaceutical industry are classified as incrementally innovative (see Casper and Matraves 2003). But given that biotechnology firms, as well as virtually all firms active in one industry, can differ in their technology intensity and innovation focus, the industry of ventures is a less good indicator for discerning their innovativeness. This is particularly true because the use of this macro-level indicator leads to an overestimation of actual patterns at the micro-level whenever data aggregation averages micro-level trends out (Herrmann 2010; Robinson 1950).

Contrary to a venture's industry, patents make it possible to discern radically and incrementally innovative firms at the micro-level. The extents both of patent applications (Soete and Wyatt 1983; Taylor 2004) and of patent citations (Akkermans et al. 2009; Schoenmakers and Duysters 2010; Singh and Fleming 2010; Trajtenberg 1990) have been used by innovation scholars as indicators of innovativeness. The basic idea is that those firms are radically innovative that applied for patents most frequently. Similarly, those firms are said to be radically innovative that hold patents which are most frequently cited in subsequently issued patents.

Using patent-based indicators, some scholars find support for specialisation effects of Germany's firms in incremental innovation and US firms in radical innovation (Akkermans et al. 2009); others do not (Taylor 2004). Importantly, though, these studies are based on the patenting behaviour of all firms, including mostly incumbent firms. Investigations of the patenting activities of new ventures as a means to identify their innovativeness are largely inexistent-for a good reason: Most new ventures do simply not patent. While also many established firms abstain from patenting, new ventures are typically very small, so that they often face the additional constraint of lacking the necessary resources for patenting their inventions. Even though they constitute particularly valid and reliable indicators, patentbased measures can thus be applied only to a very small number of ventures in order to determine their innovativeness.
The newness of a venture's good (i.e. product or service) constitutes a third way to identify whether firms are radically innovative, incrementally innovative or imitative. Using this measure offers the advantage that a firm's innovativeness can be determined both at the micro-level and for virtually all new ventures. Importantly, though, it also bears a reliability risk because it is inherently difficult to identify objective criteria that indicate whether goods are radically or incrementally new or rather imitations.

For pharmaceutical firms, an objective and, thus, reliable way of identifying a good's innovativeness was proposed by Herrmann (2008a; 2008b), who uses the chemical entities of drugs as a criterion for identifying their innovativeness. A new chemical entity constitutes an ingredient which has not been discovered thus far. Pharmaceutical companies need to indicate whether their drugs contain new chemical entities, modifications and improvement or reproductions of a known chemical entity. Accordingly, Herrmann (2008a; 2008b) considers pharmaceutical firms developing drugs including new chemical entities as radical innovators, whereas firms developing drugs on the basis of modified chemical entities are considered incremental innovators. Pharmaceutical firms producing drugs based on the reproduction of known chemical entities are considered imitators. Based on these distinctions, Herrmann (2008a; 2008b) finds slight specialisation patterns in line with the $\mathrm{VoC}$ argument that are not statistically significant. While the use of chemical entities thus serves as a reliable indicator of a venture's innovativeness, this measure can only be applied to drug developing ventures.

Another, more universally applicable way of identifying the innovativeness of a venture's good are selfreports by its founders. Entrepreneurs can simply be asked about how innovative they consider their ventures' goods. While this approach is easily applicable, it bears the risk of overestimation. Given that founders tend to be particularly self-confident and given that even product imitations tend to have a novel element as they can be produced in a particularly inexpensive manner, self-reported innovativeness tends to be overestimated. This is particularly true in countries whenever selfpromotion rather than modesty is considered a major virtue, as this is the case in the USA compared to, for example, the Netherlands.

This implies that self-reported innovativeness should be cross-checked by one or, better, more 
researchers who-based on the product description of founders-develop catalogues of product or service criteria that indicate novelty. The most comprehensive approach in this direction is the "Perfect Timing" (PT) database. Based on computer-assisted telephone interviews with founders, the data (collected between 2011 and 2018) reports the development of 874 venture creation processes for ventures active in information technology (IT) and renewable energy (RE) industries in Germany, Italy, the Netherlands, the UK and the USA.

One of the variables contained in the dataset reports the venture's innovativeness based on the novelty of its core product or service: "The innovativeness of a venture's business idea was determined in a three-step process. In the first step, the founder was asked whether his business develops a radically new, incrementally new, or imitative product or service. In a second step, the interviewer (upon completion of the interview) cross-checked the founder's answer by comparing the venture's innovativeness with the innovativeness of the other ventures about which $\mathrm{s} / \mathrm{he}$ had conducted interviews. In a third step, the person cleaning the data, again, cross-checked the degree of innovativeness indicated against the classification scheme he had developed while cleaning the data. In both step 2 and step 3, the interviewer and the data cleaner relied on the information provided by the founder as well as on online information about the venture's business idea. This three-step process made it possible to minimize the over-estimation bias that typically occurs when founders self-report the level of their business' innovativeness" (Held et al. 2018: section 3.1).

Based on this data, Table 1 provides an overview of the distribution of venture innovativeness between Germany and the USA, which illustrates specialisation effects as expected by the VoC literature. Cross-tab analyses indicate that these patterns are significant at a 0.05 level.

The work of Gramlich (2017) corroborates the results reported in Table 1. Based on her manual coding of the product novelty of 940 ventures listed on the Crunchtech database, one of the world's largest startup databases worldwide, Gramlich finds that ventures offering radically innovative goods are relatively more numerous in LMEs, whereas ventures developing moderately or incrementally new goods are more frequent in CMEs.

These analyses indicate that a venture's good can well serve as an indicator of corporate innovativeness. The indicator increases in reliability whenever one or more researchers systematically classify product or service novelty in addition to self-reports by founders. This, in turn, makes data collection for discerning product-based novelty a particularly labour-intensive exercise.

\section{Discussion and conclusions: Implications for entrepreneurship research and policymakers}

In view of this preliminary empirical evidence supporting the VoC argument that distinct institutional

Table 1 Results of crosstab analysis "country" by "innovativeness of venture product/service"

\begin{tabular}{|c|c|c|c|c|c|c|}
\hline & & & \multicolumn{3}{|l|}{ Novelty } & \multirow[t]{2}{*}{ Total } \\
\hline & & & Radical innovation & Incremental innovation & Imitation & \\
\hline \multirow[t]{6}{*}{ Country } & Germany & Count & 29 & 128 & 149 & 306 \\
\hline & & Expected count & 38.8 & 121.6 & 145.6 & 306.0 \\
\hline & & $\%$ within country & $9.5 \%$ & $41.8 \%$ & $48.7 \%$ & $100.0 \%$ \\
\hline & USA & Count & 39 & 85 & 106 & 230 \\
\hline & & Expected count & 29.2 & 91.4 & 109.4 & 230.0 \\
\hline & & $\%$ within country & $17.0 \%$ & $37.0 \%$ & $46.1 \%$ & $100.0 \%$ \\
\hline \multirow[t]{3}{*}{ Total } & & Count & 68 & 213 & 255 & 536 \\
\hline & & Expected count & 68.0 & 213.0 & 255.0 & 536.0 \\
\hline & & $\%$ within country & $12.7 \%$ & $39.7 \%$ & $47.6 \%$ & $100.0 \%$ \\
\hline
\end{tabular}

$N=536 ;$ chi-square $=6.762(0$ cells $=0 \%$ with expected count less than 5$) ; p<0.05 ;$ Cramer's $V=0.112 ; p<0.05$ 
constellations facilitate different types of entrepreneurship, which implications arise for entrepreneurship research and policymakers? To begin with, entrepreneurship research would benefit from assuming a more parsimonious approach towards investigating the link between institutions and entrepreneurship. To this end, more comprehensive data on venture innovativeness is needed in order to distinguish, in particular, between radical and incremental venture novelty. While this may imply some labour-intensive data collection efforts, data on the core $\mathrm{VoC}$ institutions has already been discerned and is thus available. Importantly, the parsimonious VoC framework, based on a core set of institutions, would enable entrepreneurship research to get away from its eclectic towards more focused analyses of the link between institutions and entrepreneurship.

Even more importantly, a VoC perspective would enable entrepreneurship research to investigate the idea of institution-based equifinality. One of the major insights resulting from the $\mathrm{VoC}$ framework is that economic actors in different institutional environments need to behave differently in order to achieve the same outcome. In other words, if economic actors across economies behave alike, this behaviour tends to result into different outcomes because of how national institutions channel their behaviour. To give an example, ventures that go public in Germany to raise funds for increasing their R\&D activities are likely to become incrementally rather than radically innovative, unlike their US counterparts, because Germany's corporate governance and education systems as well as the regulated labour market make radical innovations disproportionately difficult. To pursue radical innovation strategies, ventures in Germany may find it easier to acquire venture capital from abroad and conclude atypical contracts with their workforces (see Herrmann 2008c). Germany's entrepreneurs thus need to behave differently from their US counterparts if they want to achieve the same outcomes. If they behave alike, they will achieve different outcomes. Research into such questions of institutionally induced equifinality can offer a novel approach to investigating the link between entrepreneurial behaviour and outcomes.

The entrepreneurship literature would furthermore benefit from the finding that entrepreneurship types diffused in one institutional environment do not serve as a role model for entrepreneurship in other institutional environments. To put it bluntly, Silicon Valley is simply no role model for Germany because of its institutional differences. Such insights would allow the entrepreneurship literature to acknowledge that more than one institutional constellation exists which allows - different types (!) of - entrepreneurship to flourish. This may lead entrepreneurship research to finally move away from its wishful ideology, not to say hero worship, displaying radically innovative high-tech, high-growth entrepreneurship as the one and only desirable form of entrepreneurship. The scapegoating of less innovative ventures could finally come to an end.

The VoC insight that specific national institutions facilitate the development of different entrepreneurship types also has important implications for policy making. The VoC framework highlights that institutional constellations which are equally conducive to radically innovative, high-tech entrepreneurship and incrementally innovative, medium-tech entrepreneurship do not exist and cannot be created. Policymakers are thus faced with a trade-off and the question about which entrepreneurship type to facilitate.

To be clear, the deregulated environment of the USA clearly seems to offer that institutional environment which is most conducive to radically innovative entrepreneurship. To facilitate radically innovative entrepreneurship in Germany, policymakers would thus need to entirely deregulate Germany's institutional environment, including a change from a public pay-as-you-go scheme towards a private pension system, the abolishment of both the dual education system and labour protection, as well as modifications of the corporate governance system limiting the rights of supervisory boards.

Partial deregulations would hardly be successful, because Germany's institutional environment is complementary: Incrementally, innovative entrepreneurship is facilitated by not only one or just a few institutions (for example concerning labour protection) but also a larger institutional core (including pension, education and corporate governance systems). Taken together, these institutions form the basis for the long-term oriented, trustbased, cooperative interactions between entrepreneurs and their workforces, financiers and R\&D partners. Changing just one or a few of these institutions is unlikely to deliver the necessary basis for radically innovative entrepreneurship. The case of the Dutch economy-where tax breaks introduced about a decade ago led to a steep increase in solo self-employment without facilitating radically innovative, high-growth entrepreneurship-illustrates that some marginal 
changes would not be sufficient (Liebregts 2016). Similarly, Denmark's flexicurity model, which combines generous welfare systems with weak job security mandates (see Andersen and Svarer 2007), has also not been particularly successful in boosting high-tech entrepreneurship.

But would a full-fledged deregulation of regulated economies in general, and of Germany in particular, actually be desirable? The VoC answer is "no"! While labour protection has a negative impact on the development of radically innovative, high-tech entrepreneurship, it stimulates the development of incrementally innovative, medium-tech entrepreneurship. Accordingly, Germany is characterized by a lively start-up scene in this area (see Pahnke and Welter this issue).

Furthermore, the regulated institutional environment is at the basis of the success of Germany's Mittelstand and its core export industries. A highly qualified workforce with firm-specific skills is essential for incremental innovations and, thus, for the development of sophisticated high-quality products, which are so typical for Germany's engineering and metal-working industries. Similarly, the long-standing cooperation between companies and their stakeholders (including suppliers, banks and employees), which are fostered by Germany's corporate governance system, essentially contributes to incremental innovations at the basis of sophisticated, high-quality products. A full-fledged deregulation of Germany's economy would thus deprive the country of its competitive advantage in high-quality production.

In addition, one should keep in mind that the regulation - or deregulation - of labour and financial markets does not chiefly serve the purpose of stimulating entrepreneurship. Regulated institutions have broader societal aims, so that their deregulation has broader effects which are societally undesirable. To give just some examples: Strong wage inequalities and increasing disparities between the rich and the poor, as well as systematic underinsurance against the risks of disability, old-age poverty and illness are also typical characteristics of deregulated labour markets. Similarly, high capital market volatility and risky investments go hand in hand with deregulated financial markets. In short, a "perfect" institutional constellation that stimulates radically innovative entrepreneurship while facilitating social cohesion does not exist and cannot be created.

Does this imply that policymakers in Germany cannot do anything to facilitate radically innovative entrepreneurship? In other words, are Germany's entrepreneurs locked into an incrementally innovative, medium-tech trajectory, while US ventures are "doomed" to be radically innovative? Importantly, the answer is no! While the original VoC framework is fairly deterministic in its illustrations of how specific institutions facilitate distinct types of innovation, more recent work (Herrmann 2008b, c) explains how firms can pursue innovation strategies that are not facilitated by their institutional environment. This research illustrates that firms can defect from national institutions by "importing" the necessary capital or labour skills from abroad or by concluding atypical contracts with workforces. Policymakers can thus facilitate radical innovation in Germany and, respectively, incremental innovation in the USA by allowing for defection from the established institutions. For example, the acquisition of venture capital from abroad can be facilitated or, even, supported by the provision of public matching funds. Similarly, the employment of (foreign) workforces on the basis of atypical (often limited) contracts can be politically enabled rather than foreclosed. To conclude, while policymakers should not - and do not need tostimulate radical innovations through institutional deregulation, they can well support the entrepreneurial aim to be radically innovative by allowing for defection from the established institutional framework.

Acknowledgements This paper has strongly benefitted from the advice of Niklas Elert and Lukas Held, as well as from the sophisticated comments of Ted Baker and Friederike Welter. Any mistakes or misconceptions are my own.

Open Access This article is distributed under the terms of the Creative Commons Attribution 4.0 International License (http:// creativecommons.org/licenses/by/4.0/), which permits unrestricted use, distribution, and reproduction in any medium, provided you give appropriate credit to the original author(s) and the source, provide a link to the Creative Commons license, and indicate if changes were made.

\section{References}

Acs, Z., Parsons, W., et al. (2008a). High-impact firms: gazelles revisited. Washington D.C., Study prepared for the U.S. Small Business Administration, Office of Advocacy.

Acs, Z. J., Desai, S., et al. (2008b). Entrepreneurship, economic development, and institutions. Small Business Economics, 31(3), 219-234.

Akkermans, D., Castaldi, C., et al. (2009). Do 'liberal market economies' really innovate more radically than 'coordinated 
market economies'? Hall and Soskice reconsidered. Research Policy, 38(1), 181-191.

Amable, B. (2003). The diversity of modern capitalism. Oxford: Oxford University Press.

Amat, O. and Perramon, J. (2010). Gazelle companies: growth drivers and an evolution analysis. Universitat Pompeu Fabra, Working Paper 1244.

Andersen, T. M., \& Svarer, M. (2007). Flexicurity-labour market performance in Denmark. CESifo Economic Studies, 53(3), 389-429.

Anyadike-Danes, M., Bonner, K., et al. (2009). Measuring business growth: high-growth firms and their contribution to employment in the UK. London: NESTA.

Baumol, W. J. (1990). Entrepreneurship: productive, unproductive, and destructive. Journal of Political Economy, 98(5), 893-921.

Baumol, W. J. (2002). Entrepreneurship, innovation and growth: the David-goliath Symbiosis. Journal of Entrepreneurial Finance, 7(2), 1-10.

Baumol, W. J. (2004). Entrepreneurial enterprises, large established firms and other components of the free-market growth machine. Small Business Economics, 23(1), 9-21.

Bjørnskov, C., \& Foss, N. J. (2013). How strategic entrepreneurship and the institutional context drive economic growth. Strategic Entrepreneurship Journal, 7(1), 50-69.

BMWi. (2012). Studie über schnell wachsende Jungunternehmen (Gazellen). Berlin: Bundesministerium für Wirtschaft und Technologie.

Calcagno, P. T., \& Sobel, R. S. (2014). Regulatory costs on entrepreneurship and establishment employment size. Small Business Economics, 42(3), 541-559.

Case, S., \& Harris, D. (2012). The startup uprising: eighteen months of the startup America Partnership. Ewing Marion Kauffman Foundation, 1-49.

Casper, S. (2001). The legal framework for corporate governance: the influence of contract law on company strategies in Germany and the United States. In P. A. Hall \& D. W. Soskice (Eds.), Varieties of capitalism - the institutional foundations of comparative advantage (pp. 387-416). Oxford: Oxford University Press.

Casper, S., \& Matraves, C. (2003). Institutional frameworks and innovation in the German and UK pharmaceutical industry. Research Policy, 32(2003), 1865-1879.

Commission, E. (2010). Europe 2020: a strategy for smart, sustainable and inclusive growth: communication from the commission. Brussels: European Commission.

Cooper, A. C., \& Artz, K. W. (1995). Determinants of satisfaction for entrepreneurs. Journal of Business Venturing, 10(6), 439-457.

Davidson, C., \& Segerstrom, P. (1998). R\&D subsidies and economic growth. RAND Journal of Economics, 29(3), 548-577.

Davidsson, P., \& Henrekson, M. (2002). Determinants of the prevalence of start-ups and high-growth firms. Small Business Economics, 19(2), 81-104.

Delmar, F., Davidsson, P., et al. (2003). Arriving at the highgrowth firm. Journal of Business Venturing, 18(2), 189-216.

van der Walt, J. (2010). Entrepreneurship and the varieties of capitalism paradigm. Working Paper No. 10-10, Mercatus Center at George Mason University.

Dilli, S., N. Elert, et al. (2018). Varieties of entrepreneurship: exploring the institutional foundations of different entrepreneurship types through 'varieties-of-capitalism' arguments. Small Business Economics, 51(2), 293-320.

Ebner, A. (2010). Varieties of capitalism and the limits of entrepreneurship policy: institutional reform in Germany's coordinated market economy. Journal of Industry, Competition and Trade, 10(3-4), 319-341.

Estevez-Abe, M., Iversen, T., et al. (2001). Social protection and the formation of skills: a reinterpretation of the welfare state. In P. A. Hall \& D. W. Soskice (Eds.), Varieties of capitalism - the institutional foundations of comparative advantage (pp. 145-183). Oxford: Oxford University Press.

Eurostat (2016). High-tech industry and knowledge-intensive services (htec). available online at http://ec.europa. eu/eurostat/cache/metadata/DE/htec_esms.htm, Eurostat, the Statistical Office of the European Union.

Gramlich, E. (2017). The influence of varieties of capitalism and other contextual determinants on start-ups' innovativeness. Unpublished work, available from the author upon request, MSc thesis completed at the Innovation Studies Group of Utrecht University.

Hall, R. E., \& Jones, C. I. (1999). Why do some countries produce so much more output per worker than others? Quarterly Journal of Economics, 114(1), 83-116.

Hall, P., \& Soskice, D. (2001a). Varieties of capitalism. Oxford: Oxford University Press.

Hall, P. A., \& Soskice, D. W. (2001b). An introduction to varieties of capitalism. Varieties of capitalism - the institutional foundations of comparative advantage (pp. 1-68). Oxford: Oxford University Press.

Hancké, B., Rhodes, M., et al. (Eds.). (2007). Beyond varieties of capitalism. Oxford: Oxford University Press.

Hechavarria, D. M., \& Reynolds, P. D. (2009). Cultural norms \& business start-ups: The impact of national values on opportunity and necessity entrepreneurs. International Entrepreneurship and Management Journal, 5(4), 417-437.

Held, L., A. M. Herrmann, et al. (2018). Team formation processes in new ventures. Small Business Economics, 51(2), 441-464.

Henrekson, M. (2005). Entrepreneurship: a weak link in the welfare state? Industrial and Corporate Change, 14(3), 437-467.

Henrekson, M., \& Johansson, D. (2009). Competencies and institutions fostering high-growth firms. Foundations and Trends in Entrepreneurship, 5(1), 1-80.

Henrekson, M., \& Johansson, D. (2010). Gazelles as job creators: a survey and interpretation of the evidence. Small Business Economics, 35(2), 227-244.

Henrekson, M., \& Sanadaji, T. (2014). Small business activity does not measure entrepreneurship. PNAS, 111(5), 1760-1765.

Henrekson, M., \& Stenkula, M. (2016). Understanding entrepreneurship-definition, function, and policy. Lund: Studentlitteratur.

Herrmann, A. M. (2008a). Contrasting the resource-based view and competitiveness theories: how pharmaceutical firms choose to compete in Germany, Italy and the UK. Strategic Organization, 6(4), 343-374.

Herrmann, A. M. (2008b). One political economy, one competitive strategy? Comparing pharmaceutical firms in Germany, Italy, and the UK. Oxford: Oxford University Press.

Herrmann, A. M. (2008c). Rethinking the link between labour market flexibility and corporate competitiveness: a critique of the institutionalist literature. Socio-Economic Review, 6(4), 637-669. 
Herrmann, A. M. (2010). How macro-level sampling affects micro-level arguments: a rejoinder to Steven Casper. SocioEconomic Review, 8(2), 333-339.

Herrmann, A. M., \& Peine, A. (2011). When 'national innovation system' meet 'varieties of capitalism' arguments on labour qualifications: on the skill types and scientific knowledge needed for radical and incremental product innovations. Research Policy, 40(5), 687-701.

Hölzl, W. (2009). Is the R\&D behaviour of fast-growing SMEs different? Evidence from CIS III data for 16 countries. Small Business Economics, 33(1), 59-75.

Kenyon, T. and S. Vitols (2004). Corporate governance in Germany and the United States: key challenges for the transatlantic business community. Washington, American Institute for Contemporary German Studies; AICGS Policy Report.

Klein, B. (1996). Why hold-ups: the self-enforcing range of contractual relationships. Economic Inquiry, XXXIV(July), 444463.

Liebregts, W. (2016). Case study on Dutch solo-self employment - institutional explanations for patterns of entrepreneurial activity: the case of the Dutch task market. FIRES Work Package 5(Deliverable D5.3).

Lundvall, B.-A. (1992a). Introduction. National systems of innovation-towards a theory of innovation and interactive learning (pp. 1-19). London: Pinter Publishers.

Lundvall, B.-A. (1992b). National systems of innovation-towards a theory of innovation and interactive learning. London: Pinter Publishers.

Lundvall, B.-A. (1992c). User-producer relationships, national systems of innovation and internationalisation. National systems of innovation-towards a theory of innovation and interactive learning (pp. 45-67). London: Pinter Publishers.

Mason, C., \& Brown, R. (2013). Creating good public policy to support high-growth firms. Small Business Economics, 40(2), 211-225.

Milgrom, P. R., \& Roberts, J. (1992). Economics, organization and management. Englewood Cliffs: Prentice Hall.

Minniti, M., \& Lévesque, M. (2010). Entrepreneurial types and economic growth. Journal of Business Venturing, 25(3), 305-314.

Murphy, K. M., Shleifer, A., et al. (1990). The allocation of talent: Implications for growth. Quarterly Journal of Economics, 106(2), 503-530.

Nightingale, P., \& Coad, A. (2014). Muppets and gazelles: political and methodological biases in entrepreneurship research. Industrial and Corporate Change, 23(1), 113-143.

North, D. C. (1990). Institutions, institutional change and economic performance. Cambridge: Cambridge University Press.

OECD. (1998). Technology, productivity and job creation. Best policy practices. Paris: OECD Publishing.

OECD. (2002). High-growth SMEs and employment. Paris: Organisation for Economic Co-operation and Development.

Pahnke, A. and F. Welter (this issue). The German Mittelstand: antithesis to the Silicon Valley entrepreneurship model? Small Business Economics.

Pfeffer, J., \& Salancik, G. R. (1978). The external control of organizations: a resource dependence perspective. New York: Harper and Row.

Porter, M. E. (1985). Competitive advantage - creating and sustaining superior performance. New York: The Free Press.
Robinson, W. S. (1950). Ecological correlations and the behavior of individuals. American Sociological Review, 15(3), 351357.

Rogerson, W. P. (1992). Contractual solutions to the hold-up problem. Review of Economic Studies, 59, 777-794.

Schneider, M. R., \& Paunescu, M. (2012). Changing varieties of capitalism and revealed comparative advantages from 1990 to 2005: a test of the Hall and Soskice claims. SocioEconomic Review, 10(4), 731-753.

Schoenmakers, W., \& Duysters, G. (2010). The technological origins of radical inventions. Research Policy, 39(8), 1051-1059.

Schreyer, P. (2000). High-growth firms and employment. Paris: OECD Publishing.

Shane, S. (2009). Why encouraging more people to become entrepreneurs is bad public policy. Small Business Economics, 33(2), 141-149.

Singh, J., \& Fleming, L. (2010). Lone inventors as sources of breakthroughs: myth or reality? Management Science, 56(1), 41-56.

Sobel, R. S. (2008). Testing Baumol: Institutional quality and the productivity of entrepreneurship. Journal of Business Venturing, 23(6), 641-655.

Soete, L. G., \& Wyatt, S. M. E. (1983). The use of foreign patenting as an internationally comparable science and technology output indicator. Scientometrics, 5(1), 31-54.

Stam, E. (2014). The Dutch entrepreneurial ecosystem. SSRN Electronic Journal. https://doi.org/10.2139/ssrn.2473475.

Stenholm, P., Acs, Z. J., et al. (2013). Exploring country-level institutional arrangements on the rate and type of entrepreneurial activity. Journal of Business Venturing, 28(1), 176193.

Stinchcombe, A. L. (1965). Social structure and organizations. In J. G. March (Ed.), Handbook of organizations (pp. 142-193). Chicago: Rand McNally.

Streeck, W. (1991). On the institutional conditions of diversified quality production. In E. Matzner \& W. Streeck (Eds.), Beyond Keynesianism: the socio-economics of production and full employment (pp. 21-61). Aldershot: Edward Elgar.

Streeck, W., \& Thelen, K. (2005). Introduction: institutional change in advanced political economies. In W. Streeck \& $\mathrm{K}$. Thelen (Eds.), Beyond continuity: institutional change in advanced political economies (pp. 1-39). Oxford: Oxford University Press.

Tate, J. (2001). National varieties of standardization. Varieties of capitalism - the institutional foundations of comparative advantage. P. A. Hall and D. W. Soskice. Oxford, Oxford University Press: 442-473.

Taylor, M. Z. (2004). Empirical evidence against varieties of capitalism's theory of technological innovation. International Organization, 58(3), 601-631.

Taylor, M. Z., \& Wilson, S. (2012). Does culture still matter? The effects of individualism on national innovation rates. Journal of Business Venturing, 27(2), 234-247.

Teece, D. J. and G. Pisano (1998). The dynamic capabilities of firms. G. Dosi, D. J. Teece and J. Chytry. Oxford, Oxford University Press: 193-212.

Teubner, G. (2001). Legal irritants: how unifying law ends up in new divergences. In P. A. Hall \& D. W. Soskice (Eds.), Varieties of capitalism - the institutional foundations of 
comparative advantage (pp. 417-441). Oxford: Oxford University Press.

Trajtenberg, M. (1990). A penny for your quotes: patent citations and the value of innovations. RAND Journal of Economics, 21(1), 172-187.

Urbano, D., \& Alvarez, C. (2014). Institutional dimensions and entrepreneurial activity: an international study. Small Business Economics, 42(4), 703-716.

Vitols, S. (2001). Varieties of corporate governance: comparing Germany and the UK. In P. A. Hall \& D. W. Soskice (Eds.), Varieties of capitalism - the institutional foundations of comparative advantage (pp. 337-360). Oxford: Oxford University Press.
Vivarelli, M. (2013). Is entrepreneurship necessarily good? Microeconomic evidence from developed and developing countries. Industrial and Corporate Change, 22(6), 1453-1495.

Wiklund, J., Davidsson, P., et al. (2003). What do they think and feel about growth? An expectancy-value approach to small business managers' attitudes toward growth. Entrepreneurship Theory and Practice, 27(3), 247-270.

Williamson, O. E. (1985). The economic institutions of capitalism: firms, markets, relational contracting. New York: Free Press.

World Economic Forum. (2013). Entrepreneurial ecosystems around the globe and company growth dynamics. Davos: World Economic Forum. 